\title{
Jarlath Killeen
}

\section{Oscar Wilde and Feminism}

\section{Prolegomena'}

Oscar Wilde has recently been appropriated by feminist scholars in two distinct ways. On the one hand he is read as a proto-feminist writer, with feminist sympathies, whose editorial work publicised many women writers, and who publicly supported the causes of female education - especially to university level - female suffrage, and female participation in the workplace. However, many others have pointed out that despite this, there remains a powerful and important level of extreme misogyny running throughout his work, and that this must be read back into his political and aesthetic commitments. This article warns that, before we peremptorily attempt to assimilate Wilde into either a feminist or a misogynist paradigm, we must engage with the interpretive model in which he understood relations between the sexes: Roman Catholicism, which, while politically conservative, contained radically subversive gender possibilities.

In July 1876, Oscar Wilde sent his friend, Oxonian William Ward, a letter, outlining some of his religious concerns:

My dear Boy, I confess not to be a worshipper at the Temple of Reason. I think man's reason the most misleading and thwarting guide that the sun looks upon, except perhaps the reason of woman. Faith is, I think, a bright lantern for the feet, though of course an exotic plant in man's mind, and requiring continual cultivation. My mother would probably agree with you. Except for the people, for whom she thinks dogma necessary, she rejects all forms of superstition and dogma, particularly any notion of priest and sacrament standing between her and God. She has a very strong belief in that aspect of God we call the Holy Ghost - the divine intelligence of which we on earth partake. Here she is very strong, though of course at times trou-

1. The research upon which this paper is based was facilitated by the Government of Ireland Research Council for the Humanities and Social Sciences.

The AnaChronisT 10 (2004): 46-60 ISSN 1219-2589 
bled by the discord and jarring of the world, when she takes a dip into pessimism.

Her last pessimist, Schopenhauer, says that the whole human race ought on a given day, after a strong remonstrance firmly but respectfully urged on God, to walk into the sea and leave the world tenantless, but of course some skulking wretches would hide and be left behind to people the world again I am afraid.

I wonder you don't see the beauty and necessity for the incarnation of God into man to help us grasp at the skirts of the Infinite. The atonement I admit is hard to grasp. But I think since Christ the dead world has woken up from sleep. Since him we have lived. . .

William Ward was Wilde's best friend at Oxford, "the only man in the world I am afraid of," 3 and an ardent opponent of Anglo- and Roman Catholicism. This letter was written in the aftermath of the dramatic conversion of David Hunter Blair, the third member of Wilde's circle, who had "gone over" to the Catholic Church while in Rome in March 1875.4 Blair had set earnestly to convincing Wilde to follow him, though Wilde prudently objected that the financial threats of his father stood in the way. Sir William had been eager to see his son transfer to Oxford from Trinity College in Dublin as he had become concerned about Wilde's relationship with the Jesuits in St. Francis Xavier's Church on Gardiner Street. Writing his memories of Wilde at Oxford, Blair notes that had Wilde converted, his father would have cast him off altogether. 5 That this fear was a justified one was confirmed when Wilde's halfbrother Henry Wilson died in June 1877, his bequest to Wilde being conditional on his remaining Protestant for three years.

Richard Ellmann points out that, at the time this letter was written, "Roman Catholicism threads its way through all of Wilde's activities" (63). Ellmann's interpretation of the letter is as a statement of doubt, an intellectual means of avoiding the religious snares that Blair was setting for him (63). While Ellmann remains Wilde's best and most penetrating biographer, his reading of Wilde's attraction to Catholicism

2. Merlin Holland and Rupert Hart-Davis eds., The Complete Letters of Oscar Wilde (London: Forth Estate, 2000), pp. 25-6.

3. All parenthesised references are to this edition: Richard Ellmann, Oscar Wilde (London: Penguin, 1989), p. 43.

4. Ellmann, p. 51.

5. David Hunter-Blair, "Oscar Wilde at Magdalene College, Oxford," in Oscar Wilde: Interviews and Recollections, Volume 1, ed. E. H. Mikhail (London: Macmillan, 1979), p. 6. 
is one of the weak points of his study. Addressed to the ultra-Protestant Ward, the letter reads more like an exercise in apologetics. It attempts to wrest Ward from the "Temple of Reason" to the "bright lantern" of Faith, synonyms for, respectively, Protestantism and Catholicism. Although Protestantism was founded solidly on the Lutheran claim of "sola fide," the faith it was arching towards had by the eighteenth century become purely rational. This can be most clearly observed in the period when, as Catholic monarch, James II seemed in danger of "reconverting" England to Catholicism. The outpouring of controversial pamphlet literature that debated the issues emphasised the rational basis of the Protestant religion, ${ }^{6}$ and concomitantly lambasted Catholic dependence on a non-rational "faith," and this remains the "official" position (although the new incumbent of Lambeth Palace may offer some interesting reflections on the role of rationalism in the "modern" world). Protestantism was faith in that which was the most rational to believe: for that reason "faith" became a tautology.7

The letter makes a curious incursion into a gendered discourse of spirituality. Writing to a Protestant rationalist, Wilde warns against the dangers of relying too heavily on "man's reason" which he labels the "most misleading and thwarting guide that the sun looks upon," a direct reference to the archetypal rational philosophy, Plato's Myth of the Cave, found in the seventh book of the Republic, where the development of reason is outlined as an epistemological journey from an inadequate state of knowledge, gaping at the shadows, to a sufficient cognitive state, staring at the sun. The prisoners in the cave are the majority of mankind, the masses, "the people," doomed to view only shadows of reality and hear echoes of the truth, distorted by "their own passions and prejudices, and by the passions and prejudices of other people as conveyed to them by language and rhetoric." 8 They are in the prison-house of language. The philosopher has escaped, and has emerged from the cave into the sunlight, where he can observe the truth and is able to see the sun itself, which represents the Idea of the Good, the highest Form, the cause of all right thinking and beautiful things, and the ultimate source of truth - the generator of Reason. According to Plato, and echoed within Protestant rhetoric, this can be achieved only by activating the faculty of reason. One must have faith only in that which can be assented to as reasonable.

However, this letter suggests that to Wilde, the path to the sun of philosophical rationality is the wrong course to the real sun, the metonymic Son of God, who requires a

6. Raymond D. Tumbleson, Catholicism in the English Protestant Imagination: Nationalism, Religion, and Literature, 1660-1745 (Cambridge: Cambridge University Press, 1998).

7. Keith Thomas, Religion and the Decline of Magic: Studies in Popular Beliefs in Sixteenth and Seventeenth Century England (London: Weidenfeld \& Nicolson, 1991).

8. R. L. Nettleship, Lectures on the Republic of Plato (London: Macmillan, 1898), p. 260. 
faith-journey. Man's reason is termed the most disastrous instrument to use in the search for truth, "except perhaps the reason of woman," and here Wilde has a particular woman in mind: "My mother would probably agree with you." With this letter we are entering an especially controversial area in Wilde studies, as the issue we are forced to deal with is Wilde's 'philosophical' attitude towards women, an issue that necessarily invokes the problems associated with gender itself and the discourse of the sex war. 9

Wilde has evoked two binary oppositions, Male/Female, and Reason/Emotion, dualities at the heart of feminist theory. French feminist Hélène Cixous has made such binary oppositions the centre of her theories, ${ }^{10}$ and under the heading "Where is she?" has compiled a compendium of antitheses:

$$
\begin{aligned}
& \text { Activity/Passivity } \\
& \text { Sun/Moon } \\
& \text { Culture/Nature } \\
& \text { Day/Night } \\
& \text { Father/Mother } \\
& \text { Head/Heart } \\
& \text { Intelligible/Palpable } \\
& \text { Logos/Pathos (62). }
\end{aligned}
$$

She links these to the primary binary, the pair behind every other binary, Male/Female, and claims that all are heavily imbricated in the patriarchal value system: each opposition can be analysed as a hierarchy where the 'feminine' side is always configured as the negative, powerless instance, the lacking term. She powerfully argues that the biological opposition, Male/Female, is used to construct a series of negative 'feminine' values and behaviour characteristics, which are then imposed on, and always confused with, biological 'femaleness.' Cixous claims that Western philosophical and literary

9. For Wilde and feminism, see Victoria White, "Women of No Importance: Misogyny in the Work of Oscar Wilde," in Wilde: The Irishman, ed. Jerusha McCormack (New Haven and London: Yale University Press, 1998), 158-165; Patricia Flanagan Behrendt, Oscar Wilde: Eros and Aesthetics (London: Macmillan, 1991); Sos Eltis, Revising Wilde: Society and Subversion in the Plays of Oscar Wilde (Oxford: Clarendon Press, 1996); Melissa Knox, Oscar Wilde: A Long and Lovely Suicide (New Haven and London: Yale University Press, 1994); Gary Schmidgall, The Stranger Wilde: Interpreting Oscar (London: Abacus, 1994).

10. All parenthesised references are to this edition: Hélène Cixous, "Sorties: In and Out: Attacks/Ways Out/Forays," in The Newly Born Woman, eds. Hélène Cixous and Catherine Clement, trans. Betsy Wing, intro. Sandra M. Gilbert (Manchester: Manchester University Press, 1986), 63-132. 
thought is and has always been caught up in this endless chain of hierarchical binary oppositions, which in the end can always be reduced to the fundamental couple, Male/Female, and she locates a constant death at work in the proliferation of these binaries (63). For the first term to acquire meaning it must destroy the latter one. The couple cannot be left intact: it is a battlefield where the struggle for signifying supremacy is forever re-enacted. In the end, victory is equated with activity, and defeat with passivity. Under patriarchy, the male term is "always already" the victor. Cixous denounces this schema, and undoes logocentric ideology: she proclaims woman as the source of life, power and energy, and hails the advent of an écriture féminine which will highlight the negated sign of the binary as the creative force.

This kind of thinking is the basis of Jonathan Dollimore's assimilation of Wilde into a theory of the "transgressive aesthetic." $11 \mathrm{He}$ argues that Wilde recognises the binaries on which Western culture has been erected, and in a desire to undo the inherent oppressiveness of this construction configured a philosophical tactic to invert the binary and raise the previously 'dead' term to dominance:

(In)subordinate inversions if at all successful, provoke reaction. The result is a cultural struggle between unevenly matched contenders, a struggle in which the dominant powers, which transgressive inversion fiercely disturbs, now react fiercely against it. But the case of Wilde suggests why, as a strategy of cultural struggle, binary inversion so often provokes such a reaction ... Because in any historical instance the binary holds in place more than it actually designates, its inversion typically has effects beyond itself: inversion may for instance give impetus to cultures denigrated by its subordinate term, and simultaneously throw into disarray the cultures officially sanctioned by its dominant term..$^{12}$

In feminist terms, then, to privilege the 'feminine' side of the binary is to set in motion the struggle to deconstruct the idea of hierarchy itself.

However, if we take the letter to Ward as our starting point for such an argument, Wilde does not fit comfortably into either Cixous's or Dollimore's model. For Cixous you can either be patriarchal or deconstructive; yet by privileging "emotion" over "reason" Wilde remains strictly within binary oppositions, though he privileges the "negative" term. Here he might seem to conform to Dollimore's interpretation.

11. Jonathan Dollimore, Sexual Dissidence: From Augustine to Wilde, Freud to Foucault (Oxford: Clarendon Press, 1991), p. 64.

12. Dollimore, p. 66. 
Yet in consigning Reason to the dustbin of history Wilde retains another binary God/Man - at the core of Western civilisation, even more foundational than Man/Woman. ${ }^{13}$ Wilde placidly rejects the Protestant view of creation and asserts that not only is Reason an aspect of the sinful nature of mankind rather than the means of salvation, but that it is given to both sexes. He claims that there is an entire Western religious system based on the privileging of Faith and Emotion over Reason, Roman Catholicism, a claim which, if true, would render both Cixous's and Dollimore's conception of Western civilisation far too unsophisticated as they fail to deal with philosophies that privilege different sides of binary opposites as they encounter them, rather than as dominated by a masculinist configuration of the cosmos. In suggesting that Catholicism has a monopoly on "irrational faith" Wilde is capitalising on the claims of his contemporaries about the "unreasonableness" of Catholicism. ${ }^{14}$

Wilde is being transgressive and conservative, privileging God over Man, but Faith over Reason. The letter's position on the opposition Male/Female is more difficult to pin down. Man's reason is declared the "most misleading and thwarting guide that the sun looks upon, except perhaps the reason of woman." Reason is the chief culprit here. It is part of the fallen world. While the Protestant mind associates it with the divine intelligence, in Eden it was not one of the cultivated plants. After the Fall humanity was cursed with Reason leading eventually, to Protestantism. However, historically it has been men who have cultivated Reason, which is why Wilde labels faith "an exotic plant to man's mind," suggesting that it has long been grown by women.

Utilising the discourse of Culture/Nature, Wilde maintains that the association of woman with Nature has been to their benefit, as it has brought them closer to God, and proportionally been harmful to men, as it has led them away from God and drawn them towards Plato's sun, the god of Reason. ${ }^{15}$ It is not that faith is a property biologically inherent in women; it has merely been better cultivated by them. This exhorts

13. The binary God/Man is the foundational philosophical opposition from at least the Pythagoreans onwards within Western metaphysics, rather than Speech/Writing, as Jacques Derrida claims (in Of Grammatology, trans. Gayatri Chakravorty Spivak [Baltimore and London: The Johns Hopkins University Press, 1976], 6-27), or Man/Woman as in Cixous, p. 64.

14. E. G. Berryman, Is the Christian Religion in Accordance with Reason and Common Sense? (London: E. G. Berryman, 1884). To characterise Catholicism as a religion that pays little or no attention to reason would be misleading. In the system of Thomas Aquinas for example, reason takes a vital place. However, it always stays subordinate to faith.

15. Some ecofeminists would agree with this. They argue that mainstream feminism should stop trying to break the link between woman and nature, and claim that the problem has always been men's alienation from it. 
both sexes to adopt the conventionally 'feminine' quality of faith as the means of divine communion. Wilde assures Ward that he has misunderstood history by seeing it teleologically as the development of Reason, the movement towards a world where superstition is banished and the light of Plato's sun illuminates everything.

This position is, however, one well out of favour with many strands of contemporary feminism and with most of the elements in arguments for women's liberation. From its modern inception, the movement has been involved in the repudiation of any appropriation of the claims of reason by men and the assignation of emotion to women. ${ }^{16}$ The call for the use of Reason as a means of liberation is misguided to Wilde here in the sense that he believes that women are already liberated in religious terms (though not, it is clear, in material reality), and have only now, presumably through the phenomenon of the 'New Woman,' begun to trammel this freedom by trumpeting 'reason' as an attractive category. ${ }^{17}$ It is the integration of feminism with reason that Wilde is objecting to here. It is not that women do not possess Reason - indeed he states blandly that his mother possesses far too much of it - but that historically, they have failed to develop it. The recent move in human history towards the deployment of Reason by women is a negative one in terms of salvation history, because it is only by subordinating Reason that one can find the keys to the kingdom..$^{18}$

The problem with the dream of Reason is that it cannot cope with the unreasonableness of the universe. Its only solution to the irrational is despair. When his mother

16. See Mary Wollstonecraft, A Vindication of the Rights of Woman, ed. Miriam Brody Kramnick (Harmondsworth: Penguin, 1978); Elizabeth D. Harvey, and Kathleen Okruhlik, Women and Reason (Ann Arbor: University of Michigan Press, 1992); Genevieve Lloyd, The Man of Reason: 'Male' and 'Female' in Western Philosophy (Minneapolis: University of Minneapolis Press, 1984); Janet Radcliffe Richards, "Why Feminist Epistemology Isn't," in The Flight from Science and Reason, eds. Paul R. Gross, Norman Levitt, and Martin W. Lewis (Baltimore and London: New York Academy of Sciences, distributed by Johns Hopkins Press, 1997), 385-412.

17. For the 'New Woman' see Lyn Pykett, The 'Improper' Feminine: The Woman's Sensation Novel and the New Woman Writing (London \& New York: Routledge, 1992); Sally Ledger, "The New Woman and the Crisis of Victorianism," in Cultural Politics at the Fin de Siècle, eds. Sally Ledger and Scott McCracken (Cambridge: Cambridge University Press, 1995), 22-44.

18. See Lucy Bland, "The New Woman, the Married Woman and the Feminist: Sexual Politics in the 1890s," in Equal or Different, ed. Jane Rendell (Oxford: Blackwell, 1987), 141-164; see A. R. Cunningham, "The 'New Woman' Fiction of the 1890s," Victorian Studies 17 (1973) 177-186, for Reason and the New Woman. See also Carol McMillan, Women, Reason, and Nature: Some Philosophical Problems with Feminism (Oxford: Basil Blackwell, 1982). 
finds that intelligence does not provide reasons enough for the "discord and jarring of the world" she turns, not to faith but to "pessimism," like Schopenhauer, whose only resolution to the problem of evil is mass suicide. This is why Dollimore and Cixous are both insufficient in explaining either philosophy or Wilde, as neither concedes that patriarchy more often than not allows binary opposites to operate fluidly in discourse. Wilde privileges the 'feminine' side of one binary (Reason/Faith), the 'masculine' side of another (God/Man), and unites another binary into one (Man/Woman becomes Humanity). This also pulls the plug on attempts to paint Wilde as either a feminist, ${ }^{19}$ or a misogynist, ${ }^{20}$ because neither formulation can cope with his advocation that men and women drop the claim to reason and find faith in God. Generalising from this inability to adequately understand Wilde suggests that the kind of a priori positions advocated by a feminist philosophy fail in analysing Wilde's formulations, because much of current feminist thinking is itself caught up in a Protestant conception of the world - with 'binary oppositions' themselves a peculiarly Protestant obsession - and refuses to examine or believe in a system that jettisons reason for theism. ${ }^{21}$ It is not, ultimately, that men have to become more like women to be saved, but rather that they must look to the faith/superstitious aspect of life that women have cultivated like a plant, and grow that same aspect within themselves.

This letter gestures what has more recently and more controversially been called "The Myth of Male Power,"22 though Wilde remains on a purely spiritual plain here. ${ }^{23}$ While it is men who are given status and hold the highest office, the potent forces governing reality - the truth behind the facts, the link with God - is out of their hands primarily because of socialisation. It is significant that it was during this period, the height of the Victorian patriarchy, that a sizeable academic industry began to grow which pored over the evidence relating to the possibility that there once existed matriarchal societies worshipping goddess figures. The common view of male

19. See Declan Kiberd, Inventing Ireland: the Literature of the Modern Nation (London: Vintage, 1996), p. 7; Flanagan, p. 7; Ruth Vanita, Sappho and the Virgin Mary: Same-Sex Love and the English Literary Imagination (New York: Columbia University Press, 1996), pp. 83-88.

20. See White; Norbert Kohl, Oscar Wilde: The Works of a Conformist Rebel (Cambridge: Cambridge University Press, 1989), p. 221.

21. Camille Paglia, Sex, Art, and American Culture: Essays (London: Viking, 1993), p. 246.

22. Warren Farrell, The Myth of Male Power: Why Men are the Disposable Sex (London: Fourth Estate, 1994).

23. In other words he is not suggesting that women have not been materially oppressed throughout history. 
religious leaders in the nineteenth century was that women had a greater religious instinct than men, and a greater capacity for worship. ${ }^{24}$ Such an obsession with female sites of religious power grew during the period in which a "crisis of faith" was besieging the established churches, a crisis extrapolated from the exhortation to rationalism and the erection of a temple of Reason based on geology and the Higher Criticism - male dominated categories of study pushing the belief in science to logical conclusions. ${ }^{25}$ While male confidence in over-masculine versions of the spiritual world began to crumble a variety of alternative alliances began to form for women.

The interest in powerful female faith-links to divinity exposed the inadequacies of the prevailing models of male omnipotence and omnicompetence. The creation of a subculture of feminine knowledge tantalisingly held the possibility of a spiritual escape route for men watching the metaphysical edifice of their world crumbling under the weight of the empirical sciences. While male university faculties and churches went to academic and spiritual war with their souls at stake, women seemed to be congregating and organising a spiritual counterculture. Some sociologists have argued, controversially, that due to the historically direct role of women in childraising, they have and create a "moral community" that is unavailable to men except through their relationships with their wives and mothers who embody the virtues of this moral community. Moreover this community itself, made up as it is of mothers and wives, appears to men as a specifically female site that is available to them only through the actions of the women in their lives:

... women, the primary carers, have much more direct experience of the moral community than do men, whose own position is mediated by a few key relationships to women. Men's experience of community is as sons and lovers, so to speak. It is their mothers and wives who consequently appear to embody the virtues ... which community life entails. This is not all though. Not only are women closer to the heart of the caring community,

24. Brian Heeney, The Women's Movement in the Church of England, 1850-1930 (Oxford: Clarendon Press, 1988).

25. For the crisis of faith as a male obsession, see Ruth Y. Jenkins, Reclaiming Myths of Power: Women Writers and the Victorian Spiritual Crisis (Lewisburg: Bucknell University Press; London \& Toronto: Associated University Presses, 1995), p. 18ff; for the Genesis and geology debate see C. C. Gillespie, Genesis and Geology (New York: Harper and Row, 1959); for the Higher Criticism see M. A. Crowther, Church Embattled: Religious Controversy in Mid-Victorian England (Newton Abbot: David and Charles, 1970), and John Rogerson, Old Testament Criticism in the Nineteenth Century: England and Germany (London: S.P.C.K., 1984). 
but the web of mutual obligations and services which make it up are predominantly between women .... So the community itself does have a distinctly female character. ${ }^{26}$

This view corresponds to that of Emile Durkheim who believed that religion was not ultimately about hard theology, but rather a representation of social bonds and group consciousness, a symbolic statement about membership of family and community.

Thus, while the male Protestant churches had elevated men and rationalism, women began to predominate in three other religious areas. The first feminised religion was that of occultism with its great Occult Mother, Madame Blavatsky. ${ }^{27}$ The evidence for female influence over mysticism in this period is overwhelming, and in novels written by men, the occurrence of the mystical female demonstrates how a masculinity in crisis sought female deities to salvage them: Ayeshavn Bulwer Lytton's A Strange Story (1862); Rider Haggard's She (1887); Arabella Donne in Hardy's Jude the Obscure (1896); the Duchess of Towers in George du Maurier's Peter Ibbetson (1892); Theodora in Disraeli's Lothair (1870); Lewis Carroll's Queen of Hearts in Alice in Wonderland. ${ }^{28}$ Wilde's letter states that the Infinite wears "skirts," thus implicating him in this kind of thinking.

Instinctual values ${ }^{29}$ were proclaimed specifically female virtues by feminists in this period, the same instincts that Wilde is professing to admire in the letter at hand. The distance between men and women's intellectual drives is to be regretted for him, but regretted on the side of men. For women to move towards the use of Reason is a disastrous turn in history because it functions to misdirect the whole community, male and female, deeper into male rational factionalism and a godless society. Wilde would have

26. Geoff Dench, The Frog, the Prince, and the Problem of Men (London: Neanderthal Books, 1994), p. 129.

27. See Diana Basham, The Trial of Women: Feminism and the Occult Sciences in Victorian Literature and Society (Hong Kong: Macmillan, 1992), and Alex Owen, The Darkened Room: Women, Power, and Spiritualism in Late Victorian England (London: Virago, 1989).

28. Basham, 178-9.

29. Or lateral thinking as it has come to be termed: see the notorious Peggy McIntosh, Interactive Phases of Curricular Revision: A Feminist Perspective (Wellesley, Massachusetts, 1983); see also Alice Echols, “The taming of the Id: Feminist Sexual Politics: 1968-1983," in Pleasure and Danger: Exploring Female Sexuality, ed. C. S. Vance (Boston: Routledge and Kegan Paul, 1984), and Mary F. Belenky, Blythe M. Clincy, Nancy R. Goldberger, and Jill M. Tarrule, Women's Ways of Knowing: The Development of Self, Voice and Mind (New York: Basic Books, 1986). See also Linda Alcoff and Elizabeth Potter, eds., Feminist Epistemologies (London: Routledge, 1993). 
echoed the feminist Margaret Fuller when she argued that "The electrical, the magnetic element in women has not been fairly brought out at any period. Everything might be expected from it; she has more of it than man. This is commonly expressed by saying that her intuitions are more rapid and more correct. You will often see men of high intellect absolutely stupid in regard to the atmospheric changes, the fine invisible links which connect the forms of life around them, while common women ... will seize and delineate these with unerring discrimination." 30 Wilde would have only one adjunct to this. It would be to warn that women do not possess these features by nature but by "cultivation," hence he urges William Ward to begin to shore up this exotic plant in his psyche. His reference to "the people" is in part a reference to the feminised masses of Irish society, 'feminised' in the sense that dogma and superstition dominate their intellectual modes of conception.

Wilde holds women up as the potential transformers of society, recognising the second area of power for women: as the angels-of-the-home..$^{31}$ For this concept was not only the misogynistic repression by a patriarchal society. It was also the desperate expression of a frightened, religiously crumbling society of its belief that women could change the world by making men better creatures through their spiritual influence, recreating the now desolated church in the home. As Houghton writes, "The Victorian home was not only a peaceful, it was a sacred, place. When the Christian tradition ... was losing its hold on contemporary society, and the influence of the pastorate was declining, the living church more and more became the 'temple of the hearth.' " 32 The desperation inherent in this conception can be seen in Ruskin's argument defining the home: "This is the true nature of home - it is the place of Peace; the shelter, not only from all injury, but from all terror, doubt, and division. In so far

30. Margaret Fuller, Woman in the Nineteenth Century (Facsimile edition, University of South Carolina Press, 1980), pp. 90-91.

31. Walter E. Houghton, The Victorian Frame of Mind, 1830-1870 (New Haven: Yale University Press, 1957), pp. 341-8. The term, 'angel-in-the-house,' is of course Coventry Patmore's phrase, and was developed to its highest pitch by John Ruskin in his celebrated and attacked essay, Sesame and Lilies (1865). He saw the woman in the home as a quasi-spiritual being selflessly dispensing love and moral advice to her family, and draws an extreme division between the public and the private spheres.

32. Houghton, p. 346. For an attack on this theory, see Kate Millett, "The Debate over Women: Ruskin versus Mill," in Victorian Studies 14:1 (September, 1970) 63-82. See also Nancy Cott, "Passionlessness: An Interpretation of Victorian Sexual Ideology, 1790-1850," Signs 4 (1978) 219-236, who interestingly argues that angelic status did give women a dignity absent in other interpretations of womanhood. 
as it is not this, it is not home; so far as the anxieties of the outer life penetrate into it, and the inconsistently-minded, unknown, unloved, or hostile society of the outer world is allowed by either husband and wife to cross the threshold it ceases to be a home; it is then only a part of the outer world which you have roofed over and lighted fire in. But so far as it is a sacred place, a vestal temple, a temple of the hearth watched over by Household Gods, before whose faces none may come but those whom they can receive with love, - so far as it is this ... so far it vindicates the name and fulfils the praise, of Home." 33 Ruskin's plain desire is to prevent the crisis of faith intruding into the only sanctuary left from the pernicious influence of doubt. Hence his insistence that women cannot (must not) study theology. While Mary Daly claims that the designation of women as 'angels-of-the-home,' along with the model of the Virgin Mary, left women in a quandary as they could not identify with such sacralised idealisations thus forcing them to be "essentially identified with Eve," 34 men, with either Jesus and God the Father as their religious models, or a besieged church, looked with envy on their 'naturally' divine wives and mother, holy by virtue of their maternal connection to Mary.

Julia Kristeva claims that the emphasis on Mary within Catholicism had a debilitating effect on Catholic women: “... the blossoming of feminism in Protestant countries is due, among other things, to the greater initiative allowed women on the social and ritual plane. One might wonder if, in addition, such a flowering is not the result of a lack in the Protestant religious structure with respect to the Maternal. .."35 If we take this letter as one possible response, Wilde appears to be worried about the direction which such feminism appears to be taking. Although in late modernity women increased their participation in the outer technological world, a technological world largely shaped through the imagery of a masculinist and mechanistic Protestant theology, they have been strongly pressurised to do so in traditionally masculine ways. 'Feminine' faith has collapsed into 'masculine' reason, allowing the material world to usurp the role of the Creator, as humanity rejects its traditionally 'feminine' dependence on Him. Rejecting a theology of Mary may be one aspect of this thorough masculinising version of the physical and metaphysical world. And Mary is a key figure in the third domain of women's power in the Victorian period, and the one at the very heart of Wilde's letter, as evidenced by that cryptic reference to "the peo-

33. John Ruskin, Sesame and Lilies (Kent: George Allen, 1887), p. 136-37.

34. Mary Daly, Beyond God the Father: Towards a Philosophy of Women's Liberation (London: The Woman's Press, 1985 reprint), p. 81.

35. Julia Kristeva, "Stabat Mater," in The Kristeva Reader, ed. Toril Moi (New York: Columbia University Press, 1986), p. 167-8. 
ple," the mass of the Irish: the Catholic Church. ${ }^{36}$ The Catholic Church and its AngloCatholic ally were excoriated as "female movements" by the Established Church as they both contained a disproportionate number of active female participants. ${ }^{37}$ Octavius Ellis argued in 1868 that "The Ritual movement is a lay movement; but it is more than that; it is a female movement .... The Ritualistic clergyman is led, or rather misled, by a few ladies who have time and taste for ornamental work, for embroidering coloured stoles, chasubles, \&c., and they allow themselves no rest until they have persuaded him to wear these things. .."38

This is also audaciously hinted at in Wilde's first words: "I confess." The degenerate confessional was a recurrent theme in anti-Catholic polemic, site of sexual abuse and seduction of the lascivious 'celibate' and his gullible female victim. 39 The confessional served to undermine the authority of fathers and husbands over their daughters and wives as it reinforced the idea that God's authority over each individual was primary. The fact that women went in alone was affronting. $4^{\circ}$ Charles Chiniquy drew on these fears in his breathlessly entitled The Priest, the Woman, and the Confessional:

The husband respectfully requested the friends to leave the room with him, and shut the door, that the holy confessor might be left alone with his penitent during her general confession.

One of the most diabolical schemes, under the cover of auricular confession, had perfectly succeeded. The mother of harlots, the great enchantress of souls, whose seat is on "the seven hills," had, there, her priest to bring shame,

36. For the importance of Mary in the delineation of Protestants and Catholics see Andrew Greeley, The Mary Myth (New York: Seabury Press, 1977), and Stephen Benko, Protestants, Catholics, and Mary (Valley Forge: Judson Press, 1968).

37. John Shelton Reed, “'A Female Movement': The Feminisation of Nineteenth-Century Anglo-Catholicism,” Anglican and Episcopal History LVII: 2 (June 1988).

38. Octavius J. Ellis, Some Time Among Ritualists (London: Hatchards, 1868), p. 10-11. The link between women and Catholicism in England goes back to the Reformation. See Arthur F. Marotti, "Alienating Catholics in Early Modern England: Recusant Women, Jesuits and Ideological Fantasies," in Catholicism and Anti-Catholicism in Early Modern English Texts, ed. Arthur F. Marotti (London: Macmillan, 1999), 1-34.

39. Robert James Klaus, The Pope, the Protestants, and the Irish: Papal Aggression and Anti-Catholicism in Mid-Nineteenth Century England (New York: Garland Publishing Incorporated, 1987), p. 288-94.

40. Nigel Yates, "Jesuits in Disguise? Ritualist Confessors and their Critics in the 1870s," Journal of Ecclesiastical History 39 (1988) 202-216. 
disgrace, and damnation, under the mask of Christianity. The destroyer of souls, whose masterpiece is auricular confession, had, there, for the millionth time, a fresh opportunity for insulting the God of purity through one of the most criminal actions which the dark shades of night can conceal.

But let us draw the veil over the abominations of that hour of iniquity, and let us leave to hell its dark secrets. ${ }^{41}$

By placing himself in the seat of the penitent, Wilde vicariously identifies with the one coherent 'feminised' religion, which he sees as offering a holistic attitude for both sexes..$^{2}$ Wilde is a 'feminist' in Kristeva's terms as one who is marginalized by the patriarchal symbolic order, Victorian Protestantism. As she insists, "a feminist practice can only be negative, at odds with what already exists so that we can say 'that's not it' and 'that's still not it." "43 This allows her to claim that men can be constructed as subsidiary to the symbolic order. However, Wilde's position in 'feminised' Catholicism is marginal in England but dominant in his native Ireland. Catholic Wilde is positioned in both a minority and a majority culture, a feminised and yet a patriarchal religion, associating with a set of doctrines that render one a non-being in one culture, irrational, absent, beyond the pale of humanity, woman-like but also in some eyes woman-abusing, while at the same time is associated with the universal church, the membership of which is deconstructed and authoritarian. ${ }^{44}$ Wilde is on the edges of a patriarchal order and in the centre of it.

What Protestantism emphasises is the personal conscience, typical of which is the male scientist searching for the truth alone, while Catholicism is based on the concept of communal and inter-community worship. Wilde recognises that the community is a key feature in the gendered problems he has raised. His mother, a Protestant, has dismissed communally-held dogmas back to the population, "the people" - she does not require a confessional as she can relate to God directly. Wilde however, feels the

41. Charles Chinquy, The Priest, the Woman, and the Confessional (1874; Chino, California: 1979), p. 57.

42. Pusey's Eirenicon (1865) pointed out that "the vast system as to the Blessed Virgin" was "the special 'crux' of the Roman Church" blocking any chance of reunion with Anglicanism.

43. Julia Kristeva, "La femme ce n'est jamais ça," an Interview with psyché et po. Tel Quel 59 (1974), trans. Marilyn A. August as "Woman Can Never Be Defined," in New French Feminisms: An Anthology, eds. Elaine Marks and Isabelle de Courtivron (Brighton: Harvester, 1981), p. 137.

44. On the 'deconstructed' nature of the universal Church see Eamonn Hughes, "Joyce and Catholicism," in Irish Writers and Religion, ed. Robert Welch (Gerrards Cross, Buckinghamshire: Colin Smythe, 1992), 116-137. 
need to confess, to enter a mediation with God which involves the community, an approach which requires a faith rather than a fact. For him, Speranza has too many male values at the expense of God, and has rejected dogma as irrational. It is faith's very irrationality that attracts her son, paradoxy rather than orthodoxy.

This issue of gender also enters into the second part of the letter where Wilde attempts to justify Christian doctrine to Ward. Although Ellmann presents Wilde's position on the Atonement as one of reservation, he has misunderstood the tone of the letter: "Wilde praises the beauty, as well as the necessity, of the Incarnation, acknowledging doubts about the Atonement. 'But I think since Christ the dead world has woke up from sleep' " (63). Ellmann represents this final sentence as a statement of doubt, rather than of belief, the exact reverse of the intention of the letter itself. What Wilde actually claims is that, although the Atonement is "hard to grasp" or understand, the proof of it is that "since Christ the dead world has woken up from sleep," a perfectly orthodox position to hold. For the debate between Catholicism and Protestantism however, these issues of Incarnation and Atonement lead to a crucial crux: the position of the Virgin Mary within the economy of salvation, a key issue that feminism itself has yet to come fully to grips with.

This article has suggested that the issue of religion and religious doctrine must be tackled by any scholar or critic interested in tracing Wilde's position in the debate on gender which characterised late nineteenth century England, and that engagement with such issues cannot afford to elide the complexities of the religious traditions involved. This will mean, I suspect, that the terms 'feminist' and 'misogynist' may have to be displaced, and a discourse better able to handle the genuine complexities of lived traditions and subjects possessing at least limited agency will have to emerge. Both Wilde and Catholicism are interesting places from which this new discourse can start to come together. 